\title{
APPLICATION OF A SEMI-AUTOMATED TECHNIQUE IN LUNG LESION SEGMENTATION
}

\author{
Farli Rossi'), Asharani Aizuddin Abdul Rahni' ${ }^{2)}$ \\ ${ }^{I}$ Department of Electrical Engineering, Faculty of Engineering and Computer Science, Universitas Teknokrat Indonesia \\ ${ }^{2}$ Centre for Integrated Systems Engineering and Advanced Technologies (Integra), Faculty of Engineering and Built \\ Environment, Universiti Kebangsaan Malaysia \\ ${ }^{I}$ Bandar Lampung, Indonesia \\ ${ }^{2}$ Bangi, Malaysia \\ Email: Ifarli@teknokrat.ac.id, ${ }^{2} a$ shrani@ukm.edu.my
}

\begin{abstract}
Segmentation is one of the essential steps in automated medical diagnosis applications, which affects the overall system's accuracy. In this study, we apply a semi-automated technique that combines an active contour and low-level processing techniques in lung lesion segmentation by extracting lung lesions from thoracic Positron Emission Tomography (PET)/Computed Tomography (CT) images. The lesions were first segmented in Positron Emission Tomography (PET) images, which have been converted previously to Standardised Uptake Values (SUVs). The segmented PET images then serve as an initial contour for subsequent active contour segmentation of corresponding CT images. The Jaccard Index (JI) was employed to measure the accuracy of the segmentation result. Jaccard Index (JI) was calculated comparing the segmented lesion to alternative segmentations obtained from the QIN(Quantitative Imaging Network) lung CT segmentation challenge, which is probable by registering the whole body PET/CT images to the corresponding thoracic CT images. The results showed that the semi-automated technique (combination techniques between an active contour and low-level processing) in lung lesion segmentation has moderate accuracy with an average JI value of $0.76 \pm 0.12$.
\end{abstract}

Keyword: Lung lesions, Thoracic PET/CT images, Semi-automated segmentation techniques, Low level processing, Active contour

\begin{abstract}
Abstrak
Segmentasi adalah salah satu langkah penting dalam aplikasi diagnosis medis otomatis, yang memengaruhi keakuratan sistem secara keseluruhan. Dalam studi ini, kami menerapkan teknik semi-otomatis yang menggabungkan teknik pemrosesan kontur aktif dan tingkat rendah pada segmentasi lesi paru dengan mengekstraksi lesi paru dari citra Positron Emisi Tomografi (PET) dada / Tomografi Terkomputasi (CT). Lesi pertama kali tersegmentasi dalam citra Positron Emission Tomography (PET), yang sebelumnya telah diubah menjadi Standardized Uptake Values (SUVs). Gambar PET yang tersegmentasi kemudian berfungsi sebagai kontur awal untuk segmentasi kontur aktif berikutnya dari gambar CT yang sesuai. Jaccard Index (JI) digunakan untuk mengukur akurasi hasil segmentasi. Jaccard Index (JI) dihitung dengan membandingkan lesi tersegmentasi dengan segmentasi alternatif yang diperoleh dari tantangan segmentasi CT paru QIN, yang dimungkinkan dengan mendaftarkan citra PET / CT seluruh tubuh ke citra CT toraks yang sesuai. Hasil penelitian menunjukkan bahwa teknik semiotomatis (teknik kombinasi antara active contour dan low level processing) pada segmentasi lesi paru memiliki akurasi sedang dengan rata-rata nilai JI $0,76 \pm 0,12$.
\end{abstract}

Kata kunci: Lesi paru, citra PET / CT toraks, teknik segmentasi semi-otomatis, Pengolahan level rendah, Kontur aktif

\section{Introduction}

Lung cancer contributes to approaching 19\% of cancer deaths globally [1] and being one of the preeminent causes of death in general [2]. Serious attention needs to be taken for this type of cancer because of the high risk of death for lung diseases, especially due to the public's lack of awareness related to the lung's health [3]. Since the past few decades, there has been much effort in computer aided diagnosis (CADx) systems development for lung lesions [4]. However, they have not been as successful as the most effective clinical use of computer aided diagnosis (CADx), as in mammography [5].

In both automatic and semi-automatic computer aided diagnosis (CADx) systems, segmentation is an 
important step that affects the overall accuracy of the system. In an application for lung cancer, segmentation concerns that comprehensive anatomy must be included, especially of the lungs and respiratory system and lesion itself. Furthermore, it would be advantageous to use various imaging modalities in the system, obtained from multimodality scanners, as PET/CT, and numerous imaging procedures (e.g., thoracic $\mathrm{CT}$ in addition to PET/CT) [6].

As a functional imaging modality, positron emission tomography (PET) non-invasively monitors tumour cells' metabolic activities but lack image precision and limited spatial resolution. Otherwise, the computed tomography (CT) image provides detailed anatomical information and high spatial resolution relatively. Still, it is flawed in contrast, especially for discriminating the areas between organs at risk and tumour tissues. Also, the radiation dose calculation is depending on the information from CT images. Further, the complementary information from the two different imaging modalities has effectively developed the hybrid PET-CT segmentation [7].

Nestle et al. [8] employed some techniques of software fusion and noticed a massive change in the target volume extraction contrasted to the volume defined from CT image. Besides, El-Baz et al. [4] had reviewed the previous studies on the effect of PET on gross tumour volume (GTV) as complementing to CT. These previous studies had noticed that the fusion between PET/CT had promoted improvement of the GTV estimation. Consequently, this method is recommended for optimisation the treatment in nonsmall cell lung cancer (NSCLC) [9]. However, several well-known technical issues (for example, the improper registration between PET and CT images, PET resolution, and the exact tumour edge definition) still require more research and more investigations. Foster et al. [6] reviewed a co-segmentation algorithm for delineating functional and anatomical images simultaneously. They summarised four methods on incorporating anatomical and PET information into the same space that was including 1) random walk cosegmentation, 2) Markov random field based, 3) multivalued level set, and 4) fusion of textural feature based. Furthermore, Lian et al. [7] mentioned the recent co-segmentation method, consist of graph based, statistical, and learning-based co-segmentation methods.

This paper presents a semi-automated technique by combining the active contour and the low-level processing techniques to segment lung lesions using the information in corresponding PET and CT images of patients. The first section states the background information about the research and discusses the research gap. The rest consists of the following sections: Section 2 details the methodology, which covers the registration of the multimodality images and their segmentation, Section 3 discusses the evaluation of the methodology, the images used, results, and discussion. Then, Section 4 finalises the paper with conclusions and notes for future work.

\section{Materials and Methods}

For this work, we utilised the PET/CT scan and thoracic CT scan as imaging sources. Both have different characteristics in that PET / CT scan has a lower resolution and a wider field of view (FOV), while the thoracic CT scan has a higher resolution and a smaller FOV. The method can segment the images from only the PET/CT scan (i.e., using the PET and CT image from this multimodality scan). However, we combine this additional scan in our method due to the ground truth being typically available in thoracic CT images. Subsections 2.1 and sub-section 2.2 detail the first separately segmenting method, then the two separate scans registration and overall segmentation. In contrast, subsection 2.3 describes the segmentation of the lesion itself.

Figure 1 depicts the overall approach for segmenting and registering the two imaging sources. There are three image resources, namely whole-body PET image, whole-body CT image and thoracic CT image. Then, whole-body CT image and thoracic CT image are segmented to attain each image's lung segmentation in the overall segmentation section. Next, the segmented lung from the thoracic CT image is registered to the whole-body CT image segmented lung, obtaining a transform matrix from this process. The inverse from the transform matrix is employed to wholebody PET and CT images (detailed in the overall registration section) gaining co-registered PET and CT images.

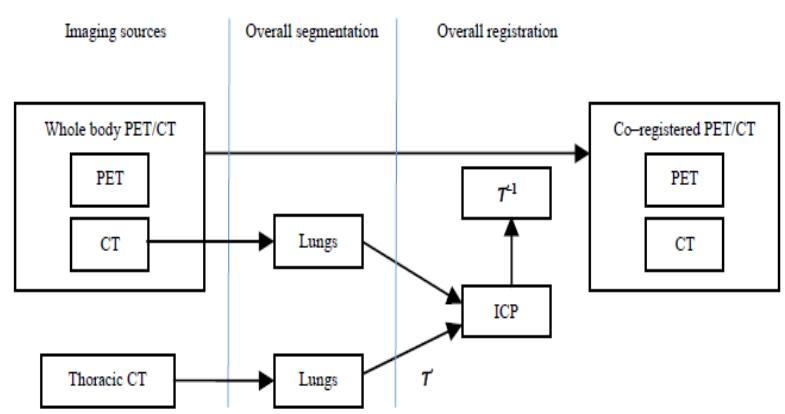

Figure 1. The procedure of overall image segmentation and registration

The intent of the overall segmentation in Figure 1 is consisting of two-objective. The first objective is a guide for the image registration process, while the second fold is to provide a concise anatomical segmentation for lesion segmentation (sub-section 2.3).

\subsection{Overall Image Segmentation}

The overall image segmentation involved three steps: 
automated multiple thresholding step, respiratory system extraction step and pulmonary tree extraction steps (as illustrated in Figure 2).

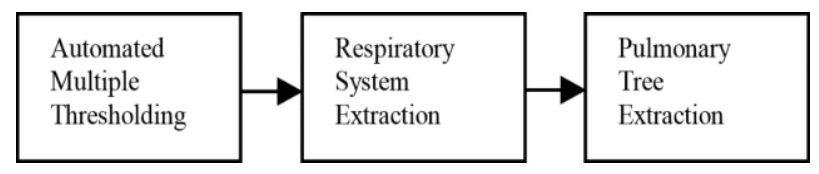

Figure 2. The flowchart of the overall image segmentation process

The overall image segmentation process is generally similar to our previous work concentrating on just thoracic CT imaging [10]-[12]. However, we adjust a similar approach to both a whole-body CT image from a PET/CT and corresponding thoracic CT scan in this work.

\subsection{Overall Image Registration}

The next stage of this method is the overall image registration involving all three imaging sources: thoracic CT image, whole-body PET and CT image. In the registration procedure, the standard iterative closest points (ICP) method [13] was applied to register the segmented lungs. This method possesses registration capability on point sets, curves, and surfaces in term of volume registration. The method algorithm is classified into three modes of transformation model: rigid, size, and affine. Further, only rigid registration was employed to transform the medical images (translation and rotation).

In the registration process, the thoracic $\mathrm{CT}$ covers a smaller FOV designated as the moving image (or data), while the whole-body CT from the PET/CT scan constitutes the fixed image (or model). The data (thoracic CT image) is registered to the model (whole-body CT image), founding a transform $\tau$ (Figure 1). However, the inverse transformation $\tau-1$ was taken to transform the PET/CT image within the frame of reference of the thoracic CT scan due to registration result assessment based on the thoracic CT scan.

\subsection{Lesion Segmentation}

We first obtained the standardised uptake value (SUV) image from the initial positron emission tomography (PET) activity for lung segmentation. The standardised uptake value (SUV) image was then first thresholded using a threshold established automatically from Otsu's method (details available in [14], [15], within a specified ROI (region of interest) or over the whole image around the lesion. The lesion was then manually selected through connected-component analysis (CCA). From thresholding, other components were connected to the lesion and the boundary was refined using the Chan-Vese [16] active contour (CV-AC) technique, which was initialised from the lesion centre obtained from the distance transform.

The lesion, which was firstly segmented from the SUV image, was further taken as an initial contour for the $\mathrm{CV}-\mathrm{AC}$ technique in segmentation applied in the coregistered thoracic $\mathrm{CT}$ image. This consecutive segmentation approach was used as a consideration that PET and CT images used have potentially been taken on largely separate time. For the cases where the lesion is situated on the boundary of the lung, a balloon active contour (B-AC) technique [17], [18], which is referring to the initial overall segmentation (Figure 2), can be used. The CV-AC technique was then used in the next segmentation process to avoid the contour propagating beyond the lung boundary.

\subsection{Evaluation Data}

The multimodality medical imaging dataset manipulated to evaluate this study was acquired from the NSCLC (non-small cell lung cancer) Radiogenomics study [19]. The research data consist of 26 datasets from different patients to evaluate the overall image registration process described in subsection 2.2. Then, only 14 datasets were selected to assess the final lesion segmentation process. We compared the outcomes with segmentations from the QIN (Quantitative Imaging Network) Lung CT Segmentation Challenge [20] for final result evaluation.

As the ground truth, the average of the multiple segmentations from the QIN (Quantitative Imaging Network) segmentations consisted of 9 segmentation images per dataset was taken for evaluation against the final result. The Jaccard Index (JI), due to an adequate indicator for the perceptual quality of segmentation [21], is utilised to measure the overlap between the results and the averaged QIN (Quantitative Imaging Network) segmentations. Then, the JI index was also employed to evaluate registration accuracy, assessing the quality of the segmented lungs from the two separate scans (The result of overall image registration) overlap each other.

\section{Results and Discussions}

The JI values for the lung and lesion overlaps obtained based on the applied method are tabulated in Table 1.

Table 1. Assessment results

\begin{tabular}{ccc}
\hline \multirow{2}{*}{ Dataset } & \multicolumn{2}{c}{ Assessment } \\
\cline { 2 - 3 } & $\begin{array}{c}\text { Lung } \\
\text { Overlap }\end{array}$ & $\begin{array}{c}\text { Lesion } \\
\text { Overlap }\end{array}$ \\
\hline Dataset 1 & 0.4232 & 0.8053 \\
Dataset 2 & 0.7801 & 0.8372 \\
Dataset 3 & 0.8678 & 0.8662 \\
Dataset 4 & 0.7033 & 0.7259 \\
Dataset 5 & 0.6495 & 0.6899
\end{tabular}




\begin{tabular}{ccc} 
Dataset 6 & 0.5155 & 0.7617 \\
Dataset 7 & 0.4049 & 0.5048 \\
Dataset 8 & 0.5838 & 0.5912 \\
Dataset 9 & 0.8633 & 0.9477 \\
Dataset 10 & 0.5299 & 0.7305 \\
Dataset 11 & 0.8093 & 0.7660 \\
Dataset 12 & 0.7597 & 0.8717 \\
Dataset 13 & 0.79 & 0.8044 \\
Dataset 14 & 0.5917 & 0.7068 \\
\hline
\end{tabular}

Based on Table 1, the results showed that the JI values for lung overlaps ranged from 0.40 to 0.86 ; meanwhile, lesion overlaps were ranged from 0.50 to 0.87 . The average JI values for lung overlaps as well as lesion overlap are shown in Figure 3. The error bars show the standard deviation of the results.

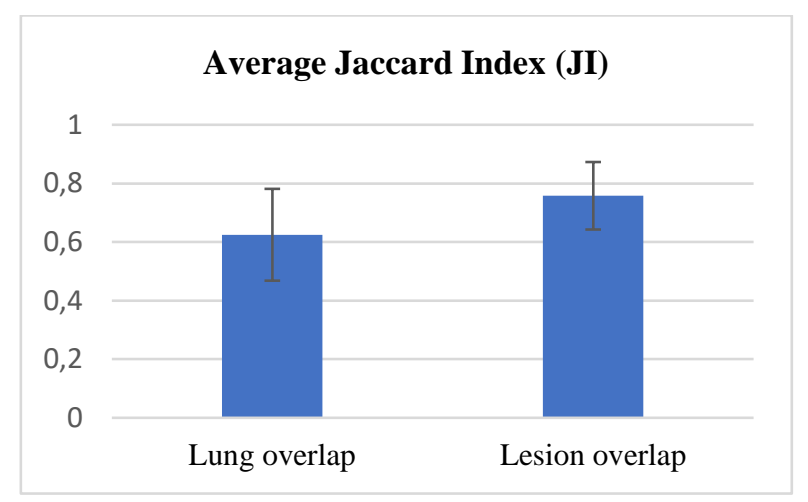

Figure 3. Image registration and segmentation results

Based on the results shown in Figure 3, we can notice that the registration between the segmented lung from the thoracic CT image and the whole-body CT image segmented lung was an acceptable degree of accuracy. This accuracy obtains from the average of JI values in a lung overlap of mostly around 0.62 even though the CT image from the whole-body PET/CT scan is rigidly registered to the thoracic CT scan. Furthermore, we can grasp that the lesion segmentation itself has quite a high degree of the JI values average about 0.76 . These values represent an overlap of the lesion with the appropriate ground truth from the average segmentation outcome in the QIN (Quantitative Imaging Network) challenge segmentation result.

Overall, using our proposed lung lesion segmentation method does not provide high accuracy based on JI values. However, this segmentation methodology is conceivably more beneficial than other methods especially the most recent technique: deep learning when the number of available training data is limited.

\section{Conclusion}

In medical diagnosis applications, segmentation is a crucial step that must be carried out accurately. This study applied the segmentation technique for lung lesion by utilising the combination of PET and CT images in a PET/CT scan and CT image from a CT scan. The outcomes revealed no major distinction of segmented lesions compared to those from the Quantitative Imaging Network (QIN) challenge. Moreover, a limitation will have occurred if the PET/CT and reference thoracic CT images themselves are exceedingly different from each other. In addition, an improved method will be needed for further research using a better image registration technique. The evaluation will also be extended to more datasets.

\section{Acknowledgement}

The authors thank the Malaysian Ministry of Higher Education and Universiti Kebangsaan Malaysia for funding this research study (research grant FRGS/1/2014/TK03/UKM/03/2 and GGPM-2013-066). The authors also gratefully acknowledge Universitas Teknokrat Indonesia for supporting data and spirit to complete this study.

\section{References}

[1] American Cancer Society, "Global Cancer Facts \& Figures," in 4th Edition, Atlanta, 2018.

[2] M. Naghavi et al., "Global, regional, and national age-sex specific all-cause and cause-specific mortality for 240 causes of death, 1990-2013: A systematic analysis for the Global Burden of Disease Study 2013," Lancet, 2015, doi: 10.1016/S0140-6736(14)61682-2.

[3] Y. Jusman, Z. Indra, R. Salambue, S. N. A. M. Kanafiah, and M. A. F. Nurkholid, "Comparison of Multi Layered Perceptron and Radial Basis Function Classification Performance of Lung Cancer Data," 2020, doi: 10.1088/17426596/1471/1/012043.

[4] A. El-Baz et al., "Computer-aided diagnosis systems for lung cancer: Challenges and methodologies," International Journal of Biomedical Imaging. 2013, doi: 10.1155/2013/942353.

[5] B. Van Ginneken, C. M. Schaefer-Prokop, and M. Prokop, "Computer-aided diagnosis: How to move from the laboratory to the clinic," Radiology. 2011, doi: 10.1148/radiol.11091710.

[6] B. Foster, U. Bagci, A. Mansoor, Z. Xu, and D. J. Mollura, "A review on segmentation of positron emission tomography images," Computers in Biology and Medicine. 2014, doi: 
10.1016/j.compbiomed.2014.04.014.

[7] C. Lian, S. Ruan, T. Denoeux, H. Li, and P. Vera, "Joint Tumor Segmentation in PET-CT Images Using Co-Clustering and Fusion Based on Belief Functions," IEEE Trans. Image Process., 2019, doi: 10.1109/TIP.2018.2872908.

[8] U. Nestle et al., "18F-deoxyglucose positron emission tomography (FDG-PET) for the planning of radiotherapy in lung cancer: High impact in patients with atelectasis," Int. J. Radiat. Oncol. Biol. Phys., 1999, doi: 10.1016/S03603016(99)00061-9.

[9] B. Abdollahi, A. Civelek, X.-F. Li, and A. ElBaz, "PET/CT Nodule Segmentation and Diagnosis," in Multi-Detector CT Imaging, 2013.

[10] F. Rossi and A. A. A. Rahni, "Combination of low level processing and active contour techniques for semi-automated volumetric lung lesion segmentation from thoracic CT images," 2016, doi: 10.1109/ISSBES.2015.7435887.

[11] F. Rossi, S. S. Mokri, and A. A. Abd. Rahni, "Development of a semi-automated combined PET and CT lung lesion segmentation framework," 2017, doi: 10.1117/12.2256808.

[12] F. Rossi and A. A. Abd Rahni, "Joint segmentation methods of tumour delineation in PET - CT images: A review," Int. J. Eng. Technol., 2018, doi: 10.14419/ijet.v7i3.32.18414.

[13] P. J. Besl and N. D. McKay, "Method for registration of 3-D shapes, InSensor fusion IV: control paradigms and data structures" 1992, doi: $10.1117 / 12.57955$.

[14] N. Otsu, "A Threshold Selection Method from Gray-Level Histograms. Automatica, 11, 23-27. References - Scientific Research Publish," Automatica, 1975.

[15] Nobuyuki Otsu, "A Threshold Selection Method from Gray-Level Histograms," IEEE Trans. Syst. Man Cybern, 1979.

[16] T. F. Chan, B. Yezrielev Sandberg, and L. A. Vese, "Active contours without edges for vectorvalued images," J. Vis. Commun. Image Represent., 2000, doi: 10.1006/jvci.1999.0442.

[17] M. Kass, A. Witkin, and D. Terzopoulos, "Snakes: Active contour models," Int. J. Comput. Vis., 1988, doi: 10.1007/BF00133570.

[18] C. Lürig, L. Kobbelt, and T. Ertl, "Hierarchical solutions for the deformable surface problem in visualisation," Graph. Models, 2000, doi: 10.1006/gmod.1999.0515.

[19] O. Gevaert et al., "Non-small cell lung cancer: identifying prognostic imaging biomarkers by leveraging public gene expression microarray data - Methods and preliminary results," Radiology, 2012, doi: 10.1148/radiol.12111607.

[20] J. Kalpathy-Cramer et al., "A Comparison of Lung Nodule Segmentation Algorithms: Methods and Results from a Multi-institutional Study," $J$. Digit. Imaging, 2016, doi: 10.1007/s10278-016- 9859-z.

[21] T. Eelbode et al., "Optimisation for Medical Image Segmentation: Theory and Practice When Evaluating With Dice Score or Jaccard Index," IEEE Trans. Med. Imaging, 2020, doi: 10.1109/TMI.2020.3002417. 